\title{
慢性血液透析患者の手根管症侯群
}

\author{
合屋忠信 藤永隆阿部哲哉岩本剛人佐々木春彦* \\ 黒木 健 文** 内藤 正俊** 中 村 定敏***市丸 喜一郎**** \\ 福岡県済生会八幡病院腎センター 同内科* 同整形外科** 北九州クリニック*** \\ 黒崎クリニック****
}

(昭和 59 年 10 月 9 日受付)

key words : 手根管症侯群，内シャント，横手根勒帯，正中神経減圧術

〈要旨〉

昭和 58 年 11 月から昭和 59 年 6 月の 8 カ月間に 21 名の慢性血液透析患者が, 手根管症侯群の治療を目的に済生会 八幡病院を受診した。患者は男 10 名女 11 名で, 平均年齢 56.8 歳（36〜77)，原疾患は全例原発性糸球体腎资であっ た。手根管症侯群の発症は両側に 10 名, 片側に 11 名と両側発症の率が高く, 透析導入から発症までの期間は 107.2士 34.1 カ月で長期透析患者に多い。自他覚所見に distal motor latency の測定を参考として診断したが, 罹患 31 手中 疼痛は 31 手 (100\%)，正中神経領域のしびれ 31 手 (100\%), Phalen test 陽性 28 手 (90.3\%)，母指球筋の萎縮 24 手 (77.4\%)にみられた。測定した 26 患肢の distal motor latency は，6 例が absent 他の 20 例の平均は $7.81 \pm 3.05$ msec で正常の約 2 倍に延長しており，また 26 例中 25 例が $4.5 \mathrm{msec}$ 以上であった. 内シャントの開存している上 肢に 22 , 閉塞した上肢に 6 , 内シャント作成の無い上肢に 3 例の発症で, 内シャント作成は手根管症侯群の発症の一 因となっている。しかし両側に発症する患者や長期透析者の発症が多いことから，内シャント作成がもたらす血行動 態の変化以外の病因の存在が推察される.16 例 18 手に手根管部の正中神経減圧術を行った. エスマルヒ駆血帯, tourniquet 圧 $250 \mathrm{mmHg}$ を使用して無血下に手掌から手関節前面への S 字状切開で広い視野をとり横手根靶帯に到達し, 正中神経を圧迫絞扼する肥厚した同靭帯を $2 \sim 4 \mathrm{~cm}$ 縦切し, 必要に応じて神経剥離術を追加した。手術の数時間後 より手の疼痛は全例消失した。術後 $6 \sim 8$ 週の所見を術前と比較すると, 手の疼痛夜間痛は全例消失, 二点識別覚に は改善傾向がみられたが, 対象が進行した重症例が多いためか, 正中神経領域のしびれ, 母指球筋の萎縮, distal motor latency の延長はいまだ改善されていなかった. 圧迫による正中神経の変性か不可逆的変化となる可能性もあり, 早期 診断早期手術が好ましいと思われる.

\section{Dialysis carpal tunnel syndrome}

Tadanobu Goya, M. D., Takashi Fujinaga, M. D., Tetsuya Abe, M. D., Taketo Iwamoto, M. D., Haruhiko Sasaki, M. D., ${ }^{*}$, Takafumi Kuroki, M. D. ${ }^{* *}$, Masatoshi Naito, M. D. ${ }^{* *}$, Sadatoshi Nakamura, M. D. ${ }^{* * *}$ and Kiichiro Ichimaru, M. D.****

Saiseikai Yahata Hospital, Kidney Center., Department of Internal Medicine*, Department of Orthopaedics**; Kitakyushu Clinic***; Kurosaki Clinic****

Carpal tunnel syndrome (CTS), an entrapment of the median nerve in the carpal tunnel, has been reported with increasing frequency in patients undergoing hemodialysis. During the last 8 months, 21 maintenance hemodialysis patients with CTS visited our hospital. These patients were 10 males and 11 females whose mean age was 56.8 . The original disease in all of them was primary glomerulonephropathy. Ten of them had bilateral CTS ; therefore 31 involved upper extremities are discussed here. The condition occurred most often in long-term hemodialysis patients. The mean duration of dialysis treatment was 107. $2 \pm 34.1$ months and only 3 out of the 21 patients were on dialysis less than 5 years. Diagnosis of CTS was based on the following symptoms and signs : hand pain, sleep

合屋 忠信 福岡県済生会八幡病院腎センタ-

₹ 805 北九州市八幡東区春の町 5-9-27(093-662-5211) 
paresthesia, numbness of the hand in a median distribution, positive Phalen test and wasting of the thenar eminence. Prolongation of distal motor latency was revealed in 25 out of 26 tested hands, it was absent in and the mean value in the other 20 was $7.81 \pm 3.05$ msec. 22 of 31 involved upper extremities had an active A-V fistula and 6 had previous surgery. Creation of an A-V fistula was statistically associated with development of $C T S$ ( $P<$ 0.002). However it seems likely that the increased incidence of CTS in bilateral hands and in long-term hemodialysis patients is due to other pathogenetic mechanisms rather than alteration in hemodynamics at the access site that increases venous pressure or the vascular "steal" phenomenon. Surgery for decompression of the median nerve at the wrist was performed on 18 hands of 16 patients. An S-shaped incision was made over the palm to the anterior aspect of the wrist with wide exposure of the flexor retinaculum. Visible thickening of the flexor retinaculum within the carpal tunnel was present in all 18 hands. They were cut by a sharp scalpel to release bundlelike constriction of the median nerve. In some instances there was venous engorgement within the neurilemmal sheath or serous exudation. After surgery, immediate relief of hand pain was felt in all patients. 6 to 8 weeks after surgery, the two-point discrimination test on the palm was improved, but numbness, wasting of the thenar eminence and prolongation of distal motor latency continued. It is important to make an early diagnosis of CTS and to perform early surgical decompression of the median nerve, because delay in treatment may cause irreversible damage to the entrapped median nerve.

\section{緒言}

手根管症侯群は正中神経が手根管部で entrapment さ れ，正中神経の麻痺症状すなわち手指の疼痛夜間痛しび れ感知賞障害運動障害をきたす疾患である。1975 年 Warren らが血液透析患者の内シャント作成肢に手根管 症侯群が高頻度に発症することを報告して以来 ${ }^{91}$ ，同様 のいくつかの報告が散見されるが，本邦での報告は少な い。血液透析患者が上肢や手, 手指に疼痛やしびれ感を 訴えても, シャント手術による血行動態の変化, Radial steal 症侯群, sore thumb 症侯群, 手術汇伴亏知覚神経 枝の損傷あるい注求毒症性末梢神経炎と漠然と診断, 放 置されることが多い. しかし手根管症侯群をよく理解し て，こうした患者の訴兑に対処してみるとこの疾患が予 想以上に多いことに気づく．最近私どもは 21 例 31 手の 慢性血液透析患者の手根管症侯群を診断し，16 例 18 手 に正中神経隇圧術を行い著効が得られたので報告する。

\section{対象・方法}

昭和 58 年 11 月から 59 年 6 月までに済生会八幡病院 整形外科を手の痛み，夜間痛，しびれ等を主訴として受 診し, 手根管症侯群と診断された慢性血液透析患者を対 象とした。診断は手指の疼痛, 夜間痛, しびれ等の自覚 症, 手の正中神経支配領域 ( $31 / 2$ 指) の知覚障害, Tinel's sign Phalen test 母指球筋の萎縮等の他覚所見に加之， distal motor latency の測定を参考にして行った。表 1 に症例を示すが, 対象患者伎男 10 名女 11 名の計 21 名で ある。このうち 11 名が片側, 10 名は両側の発症なので計 31 手を手根管症侯群と彰断した。患者の年龄は 36〜 77 歳平均 56.8 歳で, 原疾患㹥全例原発性系球体腎炎であっ た。大部分が手術の適応と診断された進行した重症例で,

\begin{tabular}{|c|c|}
\hline 慧者数 & 21 \\
\hline 男 & 10 \\
\hline 女 & 11 \\
\hline 羅患手 & 31 \\
\hline 片手 & 11 \\
\hline 両手 & 10 \\
\hline 正中神経減压術 & 18 \\
\hline 片手 & 14 \\
\hline 両手 & 2 \\
\hline 平均年齢 & 56.8 歳 $(36 \sim 77)$ \\
\hline 原疾患：原発性系球体腎症 & 21 \\
\hline
\end{tabular}

表 1 手根管症候群一症例 済生会八幡病院（昭和 58 年 11 月～ 59 年 6 月）

16 例に 18 回の正中神経減圧術を行った。麻酔は局所浸 潤麻酔の 1 例を除きすべてクーレンカンプ伝達麻酔を使 用した。エスマルヒ駆血帯を使用. $250 \mathrm{mmHg}$ 压の tourniquet で阻血し，無血下に手掌から手関節前面への S 字 状切開で広い視野をとり，長掌筋腱の尺側より横手根靯 帯に到達した。直下を走る正中神経を傷つけないように 注意し，好さみでこ机を切離し必要に応じて正中神経剥 離術を追加した。術後は手関節を金属シーネで $2 \sim 3$ 週 間固定した。術前と術後 $6 \sim 8$ 週における諸所見，すな わち手の痛み，夜間痛，正中神経領域のしびれ，Tinel's sigs Phalen test 母指球筋の萎縮, distal motor latency, 2 点識別覚, 握力について比較し, 短期間の観察ではあ るが手術の効果について検討した。

\section{結果}

患者が手の痛みを自覚しはじめた時を発症時期にする と, 透析導入から発症までの期間は $107.2 \pm 34.1$ 力月で, 


\begin{tabular}{llc}
\hline 透析導入から発症までの期間 & (月) & $107.2 \pm 34.1$ \\
発症から手術までの期間 & (月) & $27.2 \pm 25.8$ \\
利手と非利手 & 利手 & 18 \\
& 非利手 & 13 \\
内シャント作成と罹患手 & 開存 & 22 \\
& 閉塞 & 6 \\
& no surgery & 3 \\
内シャント作成から発症までの期間 (月) & $82.0 \pm 40.0$ \\
\hline
\end{tabular}

表 2 手根管症候群一発症 (mean士SD)

\begin{tabular}{ccr}
\hline 内シャント手術 & $(+)$ & 30 \\
手根管症候群 & $(+)$ & 28 \\
& $(-)$ & 2 \\
内シャント手術 & $(-)$ & 12 \\
手根管症候群 & $(+)$ & 3 \\
& $(-)$ & 9 \\
\hline
\end{tabular}

表 3 手根管症候群の発症と内シャント作成

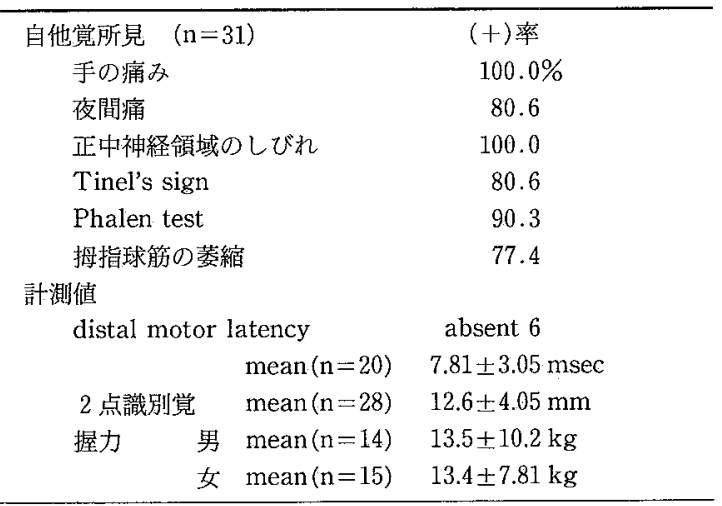

表 4 手根管症候群一症状と検査計測值 $($ mean $\pm \mathrm{SD})$
最も短い患者で 24 力月最長は 168 力月であった.透析導 入 5 年以内の発症は 3 例にすぎず他は 5 〜 年目の発 症で, 我々の症例加らは手根管症候群は長期透析患者の 合併症といえる。内シャント作成から発症までの期間は $82.0 \pm 40.0$ 力月, 最短 10 力月最長 144 力月であった。発 症から手術までの期間が $27.2 \pm 25.8$ 月と長いのは,最近 までの本症候群に対する認識の浅さを反映するものであ る. 21 名の患者で片手に 11 例, 両側の手に 10 例計 31 手 の発症であったが,このうち利手に 18 例, 非利手に 13 例 の発症であった(表 2 ). 内シャント作成と手根管症候群 発症の関連は, 開存している内シャント側に 22 手, 閉塞 後の上肢に 6 手, シャント手術のない上肢に 3 手の発症 であり，手根管症候群発症例にかぎって検討すると，内 シャント作成と本症候群の発症には関連がある（ $\mathrm{P}<$ 0.002)，(表 3 )。症状を表 4 に示すと手の痛みが $100.0 \%$, 夜間痛 $80.6 \%$, 正中神経領域のしびれ 100.0\%， 手関節前面を吒打すると手指の疼痛が増強する Tinel's $\operatorname{sign} 80.6 \%$, 手関節を屈曲位に保持することで手指の知 覚異常が発生する Phalen test は $90.3 \%$ にまた指球筋 の明らかな萎縮は $77.4 \%$ 患肢にみられた。罹患 26 手 の distal motor latency を測定したが， 6 例 $23.1 \%$ は

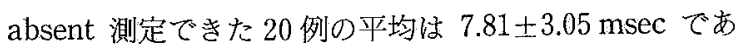
り，26例中 25 例は $4.5 \mathrm{msec}$ 以上と大幅に延長してい た. 手掌正中神経領域で測定した 2 点識別覚は $12.6 \pm 4$. $05 \mathrm{~mm}$, 握力は男 $13.5 \pm 10.2 \mathrm{~kg}$, 女 $13.4 \pm 7.81 \mathrm{~kg}$ と男女 とも著明に低下していた.正中神経減圧術を行った 18 例 中 11 例について術前と術後 $6 \sim 8$ 週の症状を比較して 表 5 に示すが，手の痛み，夜間痛は全例 $100 \%$ Tinel' s sign は $72.7 \%$ Rhalen test は $81.8 \%$ に消失または改 善していたが, 正中神経領域のしびれは $9.1 \%$ ，母指球筋 の萎縮は $0 \%$ と改善されていなかった。distal motor latency は手術前後で比較できたのは 5 例であるが， 1

\begin{tabular}{|c|c|c|c|}
\hline 自他覚所見 $(n=11)$ & 術前 $(+)$ 例 & 術後 $6 \sim 8$ 週 $(+)$ 例 & \\
\hline 手の痛为 & 11 & 0 & \\
\hline 夜間痛 & 11 & 0 & \\
\hline 正中神経領域のしびれ & 11 & 10 & \\
\hline Tinel's sign & 10 & 2 & \\
\hline Phalen test & 11 & 2 & \\
\hline 拇指球筋の萎縮 & 11 & 11 & \\
\hline $\begin{array}{l}\text { 計測値 } \\
\quad \text { distal motor latency }\end{array}$ & $(\mathrm{n}=5)$ 術前 & 術後 $6 \sim 8$ 週 & \\
\hline absent & 1 & 1 & \\
\hline mean & $9.10 \pm 1.86 \mathrm{msec}$ & $5.75 \pm 1.50 \mathrm{msec}$ & $\mathrm{P}>0.05$ \\
\hline 2 点識別覚 $(n=11)$ & $15.6 \pm 4.31 \mathrm{~mm}$ & $11.3 \pm 4.20 \mathrm{~mm}$ & $\mathrm{P}<0.05$ \\
\hline 握力 $\quad(n=10)$ & $8.45 \pm 5.62 \mathrm{~kg}$ & $9.80 \pm 4.92 \mathrm{~kg}$ & $\mathrm{P}>0.5$ \\
\hline
\end{tabular}

表 5 手根管症候群一手術と効果 (mean士SD) 


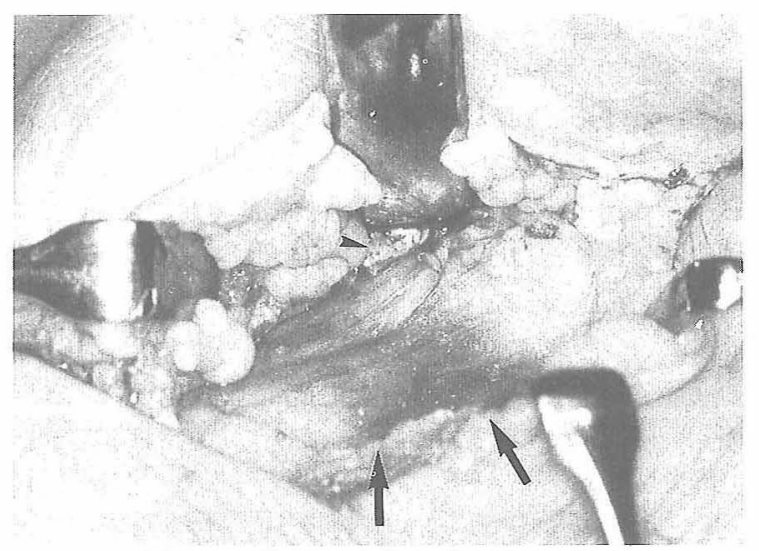

図 1 症例 ，36歳女の術中所見 横手根靶帯 (小矢印) を切離すると带状に絞扼され充 血状となった正中神経（大きな 2 つ矢印）が認められ た。

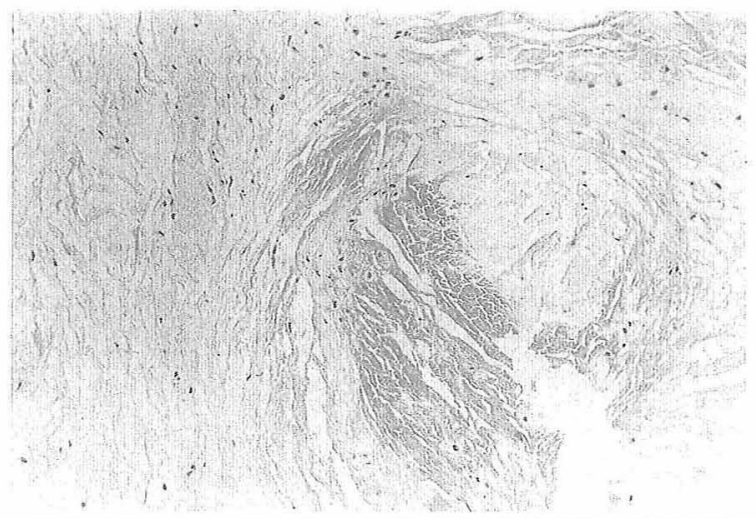

図 2 症例，70歳男の肥厚した横手根鞀带の組織所見 濃染された部はアミロイド変性に陌っている。(コン ゴーレッド染色, $\times 130)$

例は前後とも absent，残りの 4 例では前 $9.10 \pm 1.86$ msec, 後 $5.75 \pm 1.50 \mathrm{msec}(\mathrm{P}>0.05)$ で改善傾向はある が, 統計学的な有意差はなかった。2 点識別覚は前 $15.6 \pm$ $4.31 \mathrm{~mm}$, 後 $11.3 \pm 4.20 \mathrm{~mm}$ で改善された $(\mathrm{P}<0.05)$.

握力は男女合せて比較したが，術前 $8.45 \pm 5.62 \mathrm{~kg}$, 術後 $9.80 \pm 4.92 \mathrm{~kg}(\mathrm{P}>0.5)$ で有意の改善は認めなかった。正 中神経減圧術は患者を入院させて, 16 例 18 手に行い, 術 後 4 日目の退院としたが，血腫形成，神経損傷等の合併 症は皆無であった。横手根鞀帯は 18 手全例に著明な肥厚 を認め，正中神経は圧迫絞扼され扁平化しており，重症 例では絞扼されない近位遠位と比較して径が $1 / 5$ ほどに も細くなっていた。絞据された部の正中神経は光沢を失 い暗赤色化しているが，神経䩪内に明らかな静脈怒張を 認めたのは 18 手中の 6 手で,また周辺に血漿滲出液を認
めたのは 3 例のみであった(図 1 )。切除した横手根䩡带 の組織像は，浮腫性の線維組織で炎症所見はなく一部に アミロイド変性がみられるが，発症病理を示唆するよう な特徴的な所見は存在しない（図 2 )。

\section{考案}

正中神経が手根管部で entrapment される手根管症候 群は，滑膜腱鞘炎，骨の変形，肥大等局所に明確な原因 を求めることのできる場合もあるが，多くは病因不明で ある。血液透析患者の内シャント作成肢に手根管症候群 の発症が多いと報告したのは，1975 年, Warren らが最 初である ${ }^{9}$ 。本症の臨床症状は手の軽い知覚異常に始ま り，正中神経領域の疼痛，しびれ感が発現し，重症にな れば眠りより覚醒するほどになる。痛みは前腕より肩ま で放散することもある。さらに手指の正中神経領域の知 党鈍麻，母指球筋の萎縮等もみられるようになる。本症 候群の理解がないと,これらの症状は未梢神経炎やシャ ント手術に伴う血行障害が原因とみなされ放置されるこ とが多い。診断は以上の臨床症状に筋電図検查を補助に 行えば比較的容易であり，末梢神経炎と radial steal 症 候群が鑑別診断では大切である。Halter らは 48 人の血 液透析患者に筋電図検査を行い，15人（31\%）に手根管 症候群，この 15 人全員を含む 37 人 (77\%) に末梢神経 炎があったと報告している 断の基準として，末悄神経炎では distal sensory latency， distal motor latency 正中神経および尺骨神経の運動神 経伝導速度のすべてが延長するのに対し，手根管症候群 では正中神経の distal sensory latency, distal motor latency が尺骨神経に比し延長することをあげている。 我々の distal motor latency を測定した 26 例では， 6 例が absent, 残り 20 例の平均は $7.81 \pm 3.05 \mathrm{msec}$ と正常 $(4.3 \mathrm{msec})$ に比較して著明な延長を示した。血液透析患 者に抢ける手根管症候群の発生頻度はJain らは 62 人中 5 人 $(6.5 \%)$, Halter らは 48 人中 15 人 $(31 \%)$, Warren らは 36 人中 23 人 $(63.9 \%)$ と報告し様々である ${ }^{4,7,9)}$ 。 我々の 21 症例は数箇所の透析施設で手術適応の手根管 症候群と診断され受診した患者なので,これより発生頻 度を計算することはできないが，透析患者の本症の発生 頻度はかなり高いと推察できる。透析導入より発症まで の期間は Warren らは $1.8 \pm 1.3$ 年, Bosanac らは 6 〜 48 月, Halter らは 5 年以上の長期透析者に多いと 述へているる ${ }^{1,4,9)}$. 我々の症例は $2 \sim 14$ 年平均 9 年目の発 症で，5年以内の発症もわずかに 3 例と少なく, 明らか に長期透析患者に多い疾患と考えられた。透析患者の手 根管症候群の病因として内シャント作成肢における血行 動態の変化，すなわち，1）浮腫と静脈压の上昇，2） Vascular steal による虚血を考える人が多い2,3,5,8).War- 
ren は内シャント作成肢の手と対側手を比較して, 前者 が容積で $20 \%$ 増，手背静脈圧で $21 \pm 4 \mathrm{cmH}_{2} \mathrm{O}$ 高いこと より浮腫が本症の原因と考えた ${ }^{9)}$. Bosanac は手術所見 より正中神経の圧迫は外からではなく神経内静脈の怒張 と浮腫が原因と考え，したがって正中神経減圧術も横手 根鞅带切除だけでなく，顕微鏡下の神経剥離術が必要と 述べている1)。我々の 16 例 18 手の正中神経隇圧術の所 見では，肥厚した横手根靱帯による正中神経の圧迫が顕 著で正中神経の径が $1 / 5$ にまで絞抳されたものもあり, 神経内静脈の怒張等が原因と考える根拠はなかった。一 方, Jain ら, Halter らは内シャント作成と本症の発症 には統計的に有意の関連はなかったと述べ,7), また Halter らは正中神経以外の尺骨神経の entrapment neuropathy, cervical radiculopathy の発症を報告し, 内シャ ント作成以外にも病因の存在することを示唆してい る ${ }^{4)}$. 我々の対象は手根管症候群と診断されて受診した 21 例であり，この 21 例 42 手については本症と内シャン 卜作成は統計的に有意の関連がある $(\mathrm{P}<0.002)$. しか しこれは手根管症候群の発症した患者に限っての検討で あり，長期透析患者に頻度の高いこと：両側に発症する 頻度の高いこと等を考慮すると, 本症の病因は内シャン 卜作成以外にも存在すると推察される，治療は局所への ステロイド剤注入, cock-up スプリントの装着等保存的 にも行うが, 我々の手術所見から判断すれば, 正中神経 減圧術すなわち横手根䩲带切離術, 正中神経剥離術が確 実と思われる。手術時間は 30 分以内で tourniquet を使 用し阻血しても患側肢の内シャントにトラブルの発生は なかった。手術直後より手の痛みは消失して効果はドラ マティックである.手術 6 〜 週後を術前と比較すると, 手の痛み夜間痛は全例消失し， 2 点識別覚には改善がみ られるが, 正中神経領域のしびれ, 母指球筋の萎縮には 目立った改善はみられず， distal motor latency は延長 したままであった。正中神経の絞扼変性所見から判断す ると回復にかなりの時間が必要と考えられ, 圧迫の軽度 な早期の手術が勧められる。

\section{結語}

最近の 8 力月間に手根管症候群の治療を目的に当院を 受診した 21 人の慢性血液透析患者について臨床的に検 討し以下の結論を得た。

1）透析導入より発症までの期間は $107.2 \pm 34.1$ 月で あり，手根管症候群は長期透析患者に多い。

2） 21 人中 10 人が闭側の発症であり, 罹患 31 手中 28 手に内シャント作成の既往があった。内シャント作成が 本症発症の一因であるのは確実であるが, 他にも病因の 存在が推察された。

3 ）罹患手の distal motor latency は absent $23.1 \%$,
残りの平均は $7.81 \pm 3.05 \mathrm{msec}$ と大幅に延長しており, 診断には有用な検査である。

4)16例 18 手に正中神経減圧術を行った. 手術の主要 所見は横手根鞄帯の著明な肥厚とそれによる正中神経の 圧迫絞拒であった。

5 ) 手術数時間後には手の痛みは全例消失した。しか し手術 6 〜 週後でも手のしびれ，母指球筋の萎縮 distal motor latency の延長は改善されず, 今後の観察が必 要であるが, 診断治療の遅れが正中神経に不可逆性の障 害を残す可能性があるので, 早期の外科治療が望ましい。

\section{文献}

1) Bosanac, P.R., Bilder, B., Grunberg, R. W., Banach, S. F., Kintzel, J. E. and Stephens, H. W. : Post-permanent access neuropathy. Trans. Amer. Soc. Artif. Int. Organs, 23 : 162-167, 1977.

2) Bussell, J. A., Abott, J.A. and Lim, R. C. : A radial steal syndrome with arteriovenous fistula for hemodialysis. Ann. Intern. Med, 75 : 387-394, 1971.

3) Harding, A. E. and Le Fanu, J. : Carpal tunnel syndrome related to antebrachial Cimino-Brescia fistula. Journal of Neurology, Neurosurgery, and Psychiatry, $40: 511-513,1977$.

4) Halter, S. K., Delisa, J. A., Stolov, W. C., Scardapane, D. and Sherrard, D. J. : Carpal tunnel syndrome in chronic renal dialysis patients. Arch. Phys. Med. Rehabil, 62 : 197-201, 1981.

5) Holtmann, B. and Anderson, C. B. : Carpal tunnel syndrome following vascular shunts for hemodialysis. Arch. Surg, 112 : 65-66, 1977.

6) Kenzora, J. E. : Dialysis carpal tunnel syndrome. Orthopedics, $1:$ 195-203, 1978.

7) Jain, V.K., Castero, R. V. M. and Baum, J. : Carpal tunnel syndrome in patients undergoing maintenance hemodialysis. J. Am. Med. Assoc, 242 : 2868-2869, 1979.

8) Martinelli, P., Baruzzi, A., Montagna, P., Ravasio, A. and Poppi, M. : Carpal tunnel syndrome in a patient with a Cimino-Brescia fistula. Eur. Neurol, 20:478-480, 1981.

9) Warren, D. J. and Otieno, L. S. : Carpal tunnel syndrome in patients on intermittent haemodialysis. Post-grad. Med. J., 51 : 450-452, 1975 . 